UDC 366.013.01.005

\title{
PUBLIC-PRIVATE PARTNERSHIP AS AN INSTITUTE OF COMBINED PUBLIC AND PRIVATE EFFORTS TO SOLVE SOCIALLY IMPORTANT TASKS IN UKRAINE
}

UDC 366.013.01.005

${ }^{\circ} 2021$ PROKHOROVA V. V., BABICHEV A. V., YUKHMAN Y. V., VARENKO T. K.

JEL Classification: MOO

Prokhorova V. V., Babichev A. V., Yukhman Y. V., Varenko T. K.

Public-Private Partnership as an Institute of Combined Public and Private Efforts to Solve Socially Important Tasks in Ukraine

It is determined that, the Ukrainian economy is facing systemic challenges which it needs to overcome to ensure sustainable development of its communities. This requires working out new effective mechanisms and forms of interaction between the government and businesses that would balance the interests and rely on the principles of mutual gain maximization. The limited investment resources of the state render it impossible to properly finance regional socioeconomic projects and develop infrastructure. Historically, it so happened that the world would tackle the above problems, especially under unfavorable macroeconomic conditions, using the potential offered by the public-private partnership (PPP) as a form of interaction between the public and private sectors. The private sector tends to increase profits; obtaining more resources for doing business through attracting public resources; improving the efficiency of the use of their resources due to the effect of financial leverage in the merger of own resources with state resources; creation of a certain set of guarantees and preferences; removal of barriers to its development. It is concluded that, the specific nature of the state and municipal property and the limitations of the budget funding for social and infrastructure facilities, as well as the need to address socio-environmental and economic problems in an effective and efficient way determine the need to imtroduce PPP models into practice. Ukraine has embarked on the trajectory of PPP development as a pre-requisite for ensuring selfsufficiency of the state and its territorial communities. Its course is reasonably sensible because it strated with the relevant changes in the legal framework and creation of the supporting units to facilitate the PPP implementation and development. The main spheres the PPP projects are being implemented are major infrastructure facilities (electric power and heat production, water treatment, waste management, roads) and social life (health care and leisure).

Keywords: public-private partnership, mechanisms, projects, communities, infrastructure development.

DOI: https:// doi.org/10.32983/2222-0712-2021-4-50-55

Fig.: 1. Bibl.: 22.

Prokhorova Viktoriia V. - Doctor of Sciences (Economics), Professor, Head of the Department of Economics and Management, Ukrainian Engineering and Pedagogical Academy (16 Universytetska Str., Kharkiv, 61003, Ukraine)

E-mail: vkprohkorova@gmail.com

ORCID: http://orcid.org/0000-0003-2552-2131

Researcher ID: https://publons.com/researcher/3623441/viktoriya-prokhorova/

Scopus Author ID: https://www.scopus.com/authid/detail.uri?authorld=57203623016

Babichev Anatoliy V. - Candidate of Sciences (Public Administration), Pro-rector of the V. N. Karazin Kharkiv National University (4 Svobody Square, Kharkiv, 61022, Ukraine)

ORCID: https://orcid.org/0000-0002-7587-4824

Yukhman Yaryna V. - Candidate of Sciences (Economics), Senior Lecturer of the Department of Economics and Business Investment, National University «Lviv Polytechnic» (12 Stepana Bandery Str., Lviv, 79013, Ukraine)

E-mail: yaryna2003@gmail.com

ORCID: htts://orsid.org/0000-0003-3535-731X

Varenko Tetiana K. - Master, Ukrainian Engineering and Pedagogical Academy (16 Universytetska Str., Kharkiv, 61003, Ukraine)

УДК 366.013.01.005

JEL Classification: MOO

Прохорова В. В., Бабічев А. В., Юхман Я. В., Варенко Т. К. Державно-приватне партнерство як інститут поєднання державних і приватних зусиль для вирішення соціально вањливих завдань

Визначено, що необхідність подолання системних викликів, що стоять перед українською економікою, та забезпечення сталого розвитку громад вимагають формування нових ефективних механізмів і форм взаємодії владних і підприємницьких структур, що базуються на балансі інтересів і принципах максимізації взаємних вигід. Обмеженість інвестиційних ресурсів держави унеможливлює належне фінансування регіональних соціальноекономічних проєктів і розвитку інфраструктури. Вирішенню означених проблем, особливо в несприятливих макроекономічних умовах, історично у світі виступали можливості державно-приватного партнерства (ДПП) як форми взаємодії бізнесу і влади. Приватний сектор прагне, як правило, до зростання прибутку; одержання більшого обсягу ресурсів для ведення бізнесу через залучення державних ресурсів; підвищення ефективності використання свої ресурсів за рахунок ефекту фінансового левериджу при злитті власних ресурсів з ресурсами держави; створення певного набору гарантій і преференцій; зняття бар'єрів, що перешкоджають його розвитку. Зроблено висновок, що специфіка державної та комунальної власності, обмеженість бюджетного фінансування об'єктів соціальної та інфраструктурної сфери, а також необхідність ефективного вирішення соціально-екологічних та економічних проблем зумовлюють необхідність впроваджувати моделі ДПП на практиці. Україна вийшла на траєкторію розвитку ДПП, що слугує передумовою забезпечення самодостатності держави та їі територіальних громад. Його курсє цілком розумним, оскільки він грунтується на відповідних змінах законодавчої бази та створенні допоміжних підрозділів для сприяння реалізації та розвитку ДПП. Основними 
сферами реалізації проєктів ДПП є великі інфраструктурні об'єкти (виробництво електроенергії та тепла, очищення води, поводження з відходами, дороги) та соціальне життя (охорона здоров'я та дозвілля).

Ключові слова: державно-приватне партнерство, механізми, проєкти, громади, розвиток інфраструктури.

Рuс.: 1. Бібл.: 22.

Прохорова Вікторія Володимирівна - доктор економічних наук, професор, завідувач кафедри економіки та менеджменту, Українська інженернопедагогічна академія (вул. Університетська, 16, Харків, 61003, Україна)

E-mail: vkprohkorova@gmail.com

ORCID: http://orcid.org/0000-0003-2552-2131

Researcher ID: https://publons.com/researcher/3623441/viktoriya-prokhorova/

Scopus Author ID: https://www.scopus.com/authid/detail.uri?authorld=57203623016

Бабічев Анатолій Валерійович - кандидат наук з державного управління, проректор Харківського національного університету ім. В. Н. Каразіна (майдан Свободи, 4, Харків, 61022, Україна)

ORCID: https://orcid.org/0000-0002-7587-4824

Юхман Ярина Василівна - кандидат економічних наук, старший викладач кафедри економіки підприємства та інвестицій, Національний університет «Львівська політехніка» (вул. Степана Бандери, 12, Львів, 79013, Україна)

E-mail: yaryna2003@gmail.com

ORCID: htts://orsid.org/0000-0003-3535-731X

Варенко Тетяна Костянтинівна - магістр, Українська інженерно-педагогічна академія (вул. Університетська, 16, Харків, 61003, Україна)

Introduction. The Ukrainian economy is facing systemic challenges which it needs to overcome to ensure sustainable development of its communities. This requires working out new effective mechanisms and forms of interaction between the government and businesses that would balance the interests and rely on the principles of mutual gain maximization. The limited investment resources of the state render it impossible to properly finance regional socio-economic projects and develop infrastructure. Historically, it so happened that the world would tackle the above problems, especially under unfavorable macroeconomic conditions, using the potential offered by the public-private partnership (PPP) as a form of interaction between the public and private sectors.

Analysis of Research and Publications. The scientific community devotes much attention to the development of the government-business interaction theory. The recent studies of the institutional foundations and economic efficiency of PPPs find reflection in the works of such national and foreign experts as S. Bruun-Nelson [5], H. Van Ham [18], V.G. Varnavsky [19], B. Vynnytskyi [22], K. Greve [9], and others. Some studies clearly indicate that the private sector is often more efficient in rendering higher performance than the government and that combining the public and private efforts can achieve better cost-effectiveness and higher quality services for the citizens [3; 8]. The financial crises of recent years made the governments seek out and test new ways to achieve more effectivey, efficient and sustainable solutions. Such solutions proved to be partnerships with the private sector, which in their turn resulted in revisions of and changes in the PPP policies of many developing and developed states $[2 ; 4]$.

PPPs are increasingly viewd as revolutionary change in addressing public needs and ensuring public interests as they rely extensively on shared responsibility and bottom-up approach [17]. As a result, a PPP can be now called a major infrastructure procurement method integrated in the relevant policies of many countries around the world. This is mainly due to their ablity to effectively and efficiently address the ever growing demand for implementation of infrastructure proj- ects, which is largely conditioned be the population growth [4]. As for the benefits for private partners, PPPs offer them access to alternative funding and expertise from the public sector [10].

Purpose statement.The purpose of this study is to investigate the theoretical foundations of public-private partnerships, determine the legal basis and pre-requisites for PPP development in Ukriane, and study the current state and prospects thereof.

Materials and Methods. The materials used for the purposes of this study were the PPP-relevant laws and regulations of Ukraine and the publications featuring the main principles, advantages and practices of PPP from around the world, with particular focus on those from the developed countries.The method applied was that of data analysys.

Results. The term «public-private partnership» means partnership between businesses and the government which combine their efforts to implement socially important projects. In developed countries, this type of partnership has retained the interest of the government and society enabling its integration in the modern socioeconomic system and public administration processes.Today, public-private partnerships are in use in such countries as Austria, Sweden, Great Britain, Ireland, the Netherlands, the United States, France, Germany, and others. There is a wide range of PPP business models in place there. US municipalities, for instance, use cooperation between government and business on a regular basis. Out of 65 basic types of municipal activity (water supply, sewerage, garbage collection, school education, parking, etc.), 23 directly involve commercial firms. UK PPPs are always the subject of heated debate in the country when it comes to implementing projects of national importance (Eurotunnel construction, the Tube, new railways, and the like).

France has a PPP tradition of «mixed economy societies» and uses concessions. The legal grounds for the mixed economy societies go back to 1966 and 1983, and their distinguishing feature is that the law requires that the public sector and the local government should have a larger share in equity of the mixed 
economy society and therefore play a major role in its management. Limited financial resources at the federal level, in the lands and municipalities catalyze the debate as to involving the private economy in implementation of public projects $[9 ; 15]$.

In the most general sense, the term PPP denotes any combination of resources of the public and private sectors for the purpose of satisfaction of social needs. PPP refers to an array of forms of medium- and long-term interactions between the government and the private sector that serve to solve socially significant problems on a win-win basis. However, despite agreeing on understanding of the general features of PPP, the national laws specify the specific features in its definition, forms, levels of development and scope particularly applicable to their national economies. The world practices have used various organizational and legal forms of PPP: concession; rent; product sharing agreement; service contract; management contract; contract for provision of public services and execution of works; construction contract; public contract (for supply of products for public needs); technical assistance contract; contract for operation and transfer; post-privatization support contract; state equity in business structures; private equity in state-owned enterprises (joint ventures). in Some scientific publications interpret PPPs as a special form of privatization, or as an alternative thereto [19].

The public party benefits from a public-private partnership mainly in terms of: reduction of costs for provision of services, investment boosting, efficient property management, saving on financial resources of the state, use of the private sector's successful practices of doing business, risk sharing, infrastructure improvement; development of forms, creation of jobs, etc. The benefits of a public-private partnership for the private party include: attracting budget funds to the project, access to the previously restricted areas of economy, expanding the scope for soft loans under state guarantees from international and national financial institutions, simpler interaction with state licensing authorities, enhancement of the project status due to the state's participation in it, infrastructure improvement, project risk allocation.

However, one should not overlook the fact that there is a certain threat to effective PPP development. Compared to other funding mechanisms, in a PPP, partners may pursue different goals and have different motivation. Ideally, the state's interest lies in higher volumes and better quality of the public goods. Yet, lack of effective democratic institutions and the political market immaturity enable government officials to seek to use PPPs for personal gain.

The private sector aspires to increase its profits, to access public resources to be used for doing business and expanding its scope, to increase efficiency of own resources through financial leverage achieved from merging private and public resources; to create a set of guarantees and preferences and to remove barriers to the private sector development. Development of the regulatory framework for PPP can help eliminate the threat to PPP development conditioned by the difference in the interests pursued by the government and the private sector. It is not too long ago that the national practice of economic management received the legal grounds for the organizational and legal framework of public-private interactions. Thus, in 2010, the Law of Ukraine «On Public-Private Partnership» was adopted [20]. Later, the prospects of PPP development in Ukraine found reflection in the Concept of Public-Private Partnership in Ukraine for 2013-2018 approved by the Order of the Cabinet of Ministers of Ukraine [6]. Another important development was the adoption of the Law on Concession in 2019 [21] and creation of the dedicated agency designed to support and promote PPP projects implementation in Ukraine [1].

The Law of Ukraine "On Public-Private Partnership" defines a PPP as «cooperation between the state of Ukraine, the Autonomous Republic of Crimea, territorial communities represented by the relevant authorities that [...] manage the public property, local governments, the National Academy Sciences of Ukraine, national branch academies of sciences (public partners) and legal entities, with the exception of state and municipal enterprises, institutions, organizations (private partners), that is carried out on contractual arrangements [...] and has the characteristics of public-private partnership» [20].

According to this Law, the PPP characteristics include: granting the rights to manage (use, operate) an object of partnership or acquisition; creating (building, reconstructing, modernizing) a PPP object with further management (use, operation); transferring some risks to the private partner; contributing private investment into the objects of partnership. The PPP duration can range from 5 to 50 years (Ibid.). The main PPP principles are equality before the law of public and private partners, prohibition of any discrimination, agreement of public and private interests for mutual benefit, ensuring of higher efficiency as compared to the scenario without the private partner's involvement, fair distribution of PPP risks between the public and private partners, competitive selection of the private partner. PPPs can be implemented as concessions, property management, joint activities and other types of contracts. PPP objects can be the existing (particularly, reproducible) objects that are in state or municipal ownership, including subsurface site, or those to be created or acquired under the PPP contract. PPPs can be financed from the financial resources of the private partner, the funds borrowed in accordance with the established procedure, the funds of the state and local budgets, as well as other sources which are not prohibited by law (Ibid.). In this case, the private partner for conclusion of the PPP agreement (agreements) is determined exclusively on a competitive basis, except as otherwise provided by law. The law stipulates that public-private partnership in Ukraine applies in such areas as prospecting, exploration of mineral deposits and their extraction, except for those carried out under the terms of production sharing agreements; production, transportation and supply of heat and distribution and supply of natural gas; construction and/or operation of motorways, roads, railways, runways at airfields, bridges, overpasses, tunnels and subways, sea and river ports and their infrastructure; engineering; water collection, purification and distribution; health care; tourism, recreation, recreation, culture and sports; ensuring the functioning of irrigation and drainage systems; waste management, except for collection and transportation; production, distribution and supply of electricity; real estate management; provision of social services, management of a social institution; production and implementation of energy-saving technologies, construction and overhaul of residential buildings completely or partially destroyed as a result of hostilities in the territory of the anti-terrorist operation; provision of educational and health services; management of architectural monuments and 
cultural heritage. The government may also decide to apply public-private partnership in other area, except for the types of economic activity that the law prescribes to be carried out by state enterprises, institutions and organizations [16]. The state policy in PPP support in Ukraine primarily relies on the institutional approach to addressing this issue. To encourage and promote PPPs in Ukraine, there have been created a designated subdivision at the Ministry of Economic Development,

Trade and Agriculture of Ukraine and a public organization "Agency for Public-Private Partnership Support". Their goal is to acquaint project initiators from the public sector with the processes of initiation, preparation and implementation of PPP projects. According to the Investment Department at the Min- istry of Economy of Ukraine, as of 01.01.2021, there were 192 PPP agreements concluded by the central and local executive agencies in Ukraine, of which 39 are being implemented (29 of them being concession agreements, 6 - joint venture agreements, and 4 - other types) and 153 are not being implemented (118 are not being executed, 35 - terminated/expired) (Ministry of Infrastructure of Ukraine, 2021).The PPP projects currently in implementation in Ukraine come from such important areas as electric power and heat production, water treatment, waste management, roads, health care and leisure (See Fig. 1).

And it is a considerningly a good sign because the relevant legal framework is being texted in diverse environments and covers all the major shepres of life.

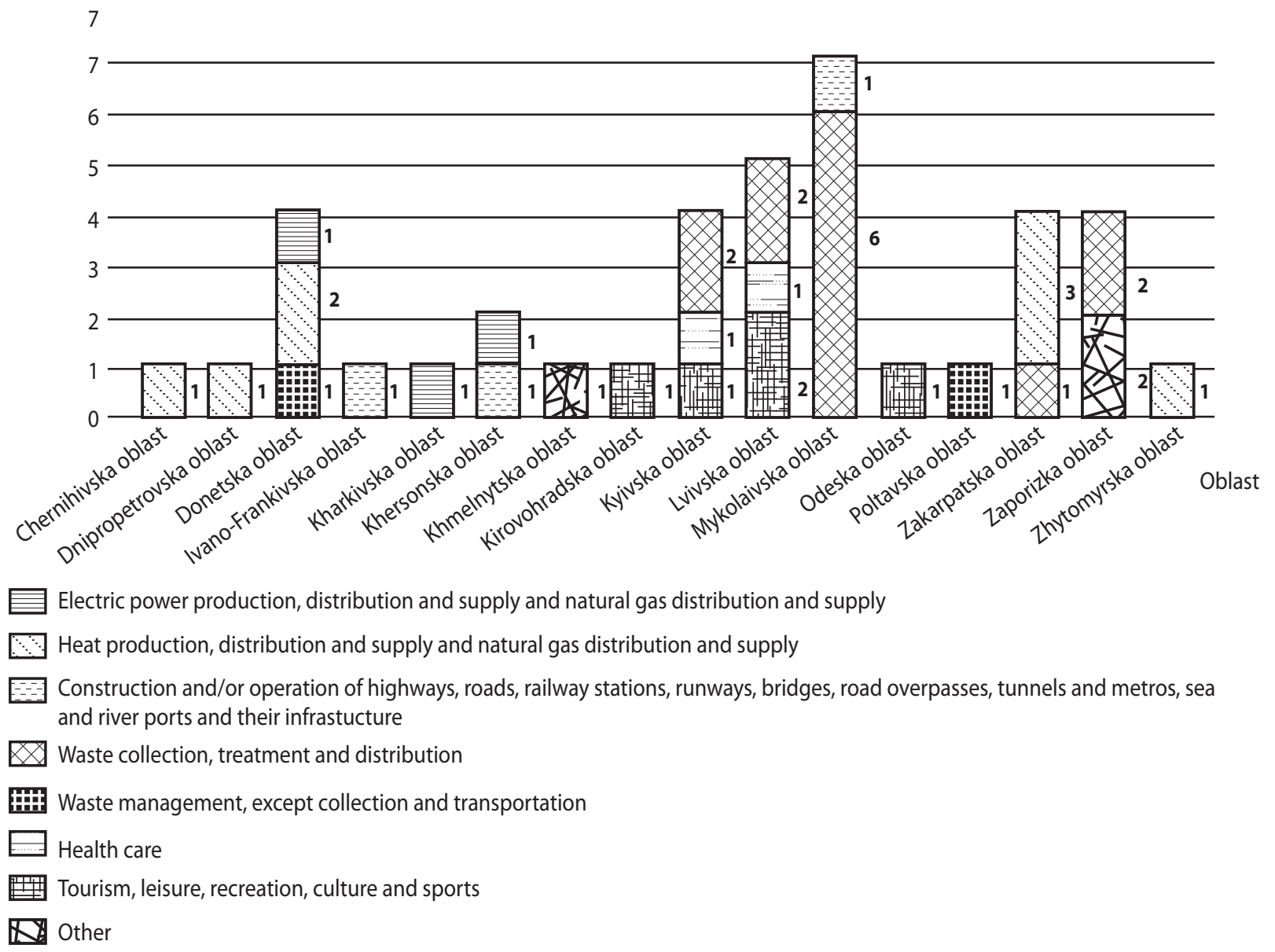

Fig. 1. PPP agreements being executed in Ukraine as of 01.01.2021 [12]

According to the recently adopted Law of Ukriane «On Concession» [21], a concession project is to be implemented between five and fifty years. It, however, does not apply to agreements related to construction and operation of roads, for which the minimum term of the agreement is ten years. Practice shows that the project will either start working within this period, or there is no chance of success, and the public party will initiate the process of property hand-over. When going for a concession agreement, it is worthwhile taking into account the most common reason for failures in such ageements, which is mere lack of active action to launch the project. The requirements of the effective laws determine that concession and PPP agreements rely on the principles of opennes, equality and non-discrimination. On the background of the decentralization reform taking place in Ukraine, the main direction in development of effective mechanisms for implementation of PPP and concession projects is through improvement of the regulatory and legal framework [11].

The economic literature mentions various PPP forms and models [13; 22]. V. H. Varnavsky [19] points out that PPPs can take many forms, including various types of contracts: contracts that the state enters into with private organizations for execution of works and public services, management and supply of various products to satisfy public needs; technical assistance contracts; lease contracts that provide for transfer by the state for lease to the private sector of its property (buildings, 
structures, production equipment) and production sharing agreements; public-private enterprises; concessions. The effective legal framework and practices of doing business in Ukraine show that the main forms of public-private partnership are as follows: service contracts, concessions, financial leasing, rent, joint ventures (public-private) and production sharing agreements [13]. The PPP practices in the developed countries demonstrate that the public-private partnership scenarios find reflection in different models depending on the form of participation in them, as well as the ownership type of the object under the contract, risk sharing, cooperation duration, etc.

According to S. Davies [7], there are five main PPP models: greenfield projects, divestiture, concessions, management and outsourcing contracts, and leasing. And each model can be executed in a variety of PPP forms depending on the specific conditions of each particular project and the specific nature of a particular industry. At the same time, it is important to remember that a PPP is an alternative to privatization of state and municipal property that combines the advantages that both the public and the private sectors can offer. Among such are social and environmental responsibility; public accountability and prioritization of environmental standards observance in nature management in business activities; the entrepreneurial approach to the development of financial resources and the use of innovations in production management.State or territorial communities usually cannot organize a profitable business in quite a few sectors of economy themselves, and they are limited in their financial and production resources. The limitations of the regional development budget hamper provision of an adequate financial and economic framework for sustainable economic and ecosystem-based management at enterprises.

It is impossible for the state, the private sector, or nonprofit structures alone (independently) to achieve the diverse, and sometimes even conflicting, priority goals in management at the level of territorial communities that comply with the principles of the public policy.

PPP models are varied. They determine the main phases of cooperation covering creation, ownership, operation and transfer of facilities. Thus, BOT (Build-Operate-Transfer) means that the concessionaire creates an object at their expense in exchange for the right they are granted upon completion of construction to operate it for a period sufficient to ensure return on investment. Once this period expires, the object is handed over to the state. The concessionaire has the right to use, but not the ownership of the object whose owner is the state.Under the BOOT (Build-Own-Operate-Transfer) model, the private partner is granted the right to both use and own the object for the term of the agreement, upon expiration of which it is handed over to the public authorities [14]. Considering that the legal framework in Ukraine is still comparatively young, and the practice of PPP and concession projects in the country cannot boast successfully executed projects that have gone through all stages of a full-fledged PPP or concession project, the "SPILNO" PPP Management Office was created at the Ministry of Infrastructure of Ukraine in 23016 with the assistance of the Western NIS Enterprise Fund. Its main objectives are to ensure timely and effective launch and development of the PPP mechanism in Ukraine, to help change the Ukrainina legislation, and to see to the implementation of the first three pilot PPP projects in the country. While the aspirations and attempts of Ukraine to adapt and implement PPP practices are applaudable, they may not be enough to ensure a success in this undertaking. PPP projects are rather complicated and longterm and require that the private partners, as well as international financial institutions have a sufficient degree of trust in the government of the country to venture engaging in such projects. This may constitute a solid challenge considering the still unresolved conflict brewing in the east of Ukraine and the tendency to dramatically changing the governments every five years when elections take place. Another reason for concern is the fact that there have been no successful examples of PPP projects implementation. Understandably, no precedents may mean certain reluctancy from the private partners to be pioneers. On the bright side, though, the country has managed to at least start a few PPP projects, which is a good sign, all things considered. How many of those will see its successful completion, time will show, but the foundation has been laid.

Conclusions. The specific nature of the state and municipal property and the limitations of the budget funding for social and infrastructure facilities, as well as the need to address socio-environmental and economic problems in an effective and efficient way determine the need to imtroduce PPP models into practice. Ukraine has embarked on the trajectory of PPP development as a pre-requisite for ensuring self-sufficiency of the state and its territorial communities. Its course is reasonably sensible because it strated with the relevant changes in the legal framework and creation of the supporting units to facilitate the PPP implementation and development. The main spheres the PPP projects are being implemented are major infrastructure facilities (electric power and heat production, water treatment, waste management, roads) and social life (health care and leisure).

\section{LITERATURE}

1. Agency on Support Public-Private Partnership. 2021. URL: https://pppagency.me.gov.ua/about/

2. Akintoye A., Beck M., Kumaraswamy M. Public Private Partnerships: A Global Review. Routledge, 2015.

3. Ara F. Public Private Partnership: Success and Potential Challenges. Lap Lambert Academic Publishing GmbH KG, 2011.

4. Bogdanowicz P., Caranta R., Telles P. (Eds.). Public-Private Partnerships and Concessions in the EU: An Unfinished Legislative Framework. Edward Elgar Publishing, 2020.

5. Бруун-Нільсен С. Важливі положення договору про державно-приватне партнерство:уроки водного сектору // Радник в сфері публічних закупівель. 2015. URL: https://radnuk.com. ua/praktyka_zakupivel/nadporogi/vazhlyvi-polozhennia-dohovorupro-derzhavno-pryvatne-partnerstvo-uroky-vodnoho-sektru

6. Про схвалення Концепції розвитку державно-приватного партнерства в Україні на 2013-2018 роки : Розпорядження Кабінету Міністрів України від 14.08.2013 № 739-р. URL: https://zakon.rada.gov.ua/laws/show/739-2013-p

7. Davies S., Fairbrother P. Private Finance Initiative (PFI) and Public Private Partnerships (PPPs): Definitions and Sources. School of Social Science, Cardiff University. Working Paper Series, 2003.

8. Delmon J. Public-Private Partnership Projects in Infrastructure: An Essential Guide for Policy Makers. Cambridge University Press, 2017.

9. Greve C. Public-Private Partnerships in Scandinavia. International Public Management Review. 2003. No. 4 (2). P. 59-69. 
10. Heydari M., Lai K. K., Xiaohu Z. Corruption, Infrastructure Management and Public-Private Partnership: Optimizing through Mathematical Models. Routledge, 2021.

11. Косач І. А., Дегтярьов А. В. Розвиток державно-приватного партнерства в умовах децентралізації влади в Україні. Державне управління: удосконалення та розвиток. 2020. № 3. DOI: $10.32702 / 2307-2156-2020.3 .2$

12. Ministry of Infrastructure of Ukraine. (2021). Who we are. URL: https://mtu.gov.ua/en/content/hto-mi-e.html

13. Мішенін $\epsilon$. Концептуальні засади розвитку механізмів державно-приватного партнерства в лісоресурсній сфері. Економіст. 2010. № 12. С. 23-26.

14. Мішеніна Н. В., Ярова І. Є., Мішеніна Г. А. Розвиток механізмів державно-приватного партнерства у сфері природогосподарювання в умовах децентралізації. Маркетинг і менеджмент інновацій. 2017. № 1. C. 319-330. URL: http://nbuv.gov. ua/UJRN/Mimi_2017_1_31

15. Щодо розвитку державно-приватного партнерства як механізму активізації інвестиційної діяльності в Україні : аналіт. записка / Національний інститут стратегічних досліджень. URL: https://niss.gov.ua/doslidzhennya/ekonomika/schodo-rozvitkuderzhavno-privatnogo-partnerstva-yak-mekhanizmu-aktivizacii

16. Онегіна В. М., Батюк Л. А. Державно-приватне партнерство та розвиток сільських територій в Україні. Актуальні проблеми інноваційної економіки. 2017. № 2. С. 64-71. URL: http://nbuv.gov.ua/UJRN/apie_2017_2_11

17. Valaguzza S., Parisi E. Public Private Partnerships: Governing Common Interests, 2020.

18. Van Ham H. Public-Private Partnerships: Assessing and Managing Risks in Port Development. Public Management Review. 2011. Vol. 3 (4). P. 593-616.

19. Варнавский В. Г., Клименко А. В., Королев В. А. Государственно-частное партнерство: теория и практика. МоСКва : ГУ-ВШЭ, 2010. 287 с.

20. Про державно-приватне партнерство: Закон України від 01.07.2010. № 2404-VI. URL: https://zakon.rada.gov.ua/laws/ show/2404-17\#Text

21. Про концесії : Закон України від 03.10.2019 № 155-IX. URL: https://zakon.rada.gov.ua/laws/show/997-14

22. Винницький Б., Лендьел М., Онищук Б., Сегварі П. Досвід та перспективи впровадження державно-приватних партнерств в Україні та за кордоном. Київ : К.І.С., 2008. 294 с. URL: https://regionet.org.ua/files/PPP_Report_CIDA_2008_ua.pdf

\section{REFERENCES}

Agency on Support Public-Private Partnership. 2021. https:// pppagency.me.gov.ua/about/

Akintoye, A., Beck, M., and Kumaraswamy, M. Public Private Partnerships: A Global Review. Routledge, 2015.

Ara, F. Public Private Partnership: Success and Potential Challenges. Lap Lambert Academic Publishing GmbH KG, 2011.

Bogdanowicz, P., Caranta, R., and Telles, P. Public-Private Partnerships and Concessions in the EU: An Unfinished Legislative Framework. Edward Elgar Publishing, 2020.

Bruun-Nilsen, S. "Vazhlyvi polozhennia dohovoru pro derzhavno-pryvatne partnerstvo: uroky vodnoho sektoru" [Important Provisions of the Public-private Partnership Agreement: Lessons From the Water Sector]. Radnyk v sferi publichnykh zakupivel. 2015. https://radnuk.com.ua/praktyka_zakupivel/nadporogi/vazhlyvi-polozhennia-dohovoru-pro-derzhavno-pryvatne-partnerstvo-uroky-vodnoho-sektru
Davies, S., and Fairbrother, P. Private Finance Initiative (PFI) and Public Private Partnerships (PPPs):Definitions and Sources. School of Social Science, Cardiff University. Working Paper Series, 2003.

Delmon, J. Public-Private Partnership Projects in Infrastructure: An Essential Guide for Policy Makers. Cambridge University Press, 2017.

Greve, C. "Public-Private Partnerships in Scandinavia". International Public Management Review, no. 4(2) (2003): 59-69.

Heydari, M., Lai, K. K., and Xiaohu, Z. Corruption, Infrastructure Management and Public-Private Partnership:Optimizing through Mathematical Models. Routledge, 2021.

Kosach, I. A., and Dehtiaryov, A. V. "Rozvytok derzhavno-pryvatnoho partnerstva v umovakh detsentralizatsii vlady v Ukraini" [Development of Public-private Partnership in the Conditions of Decentralization of Power in Ukraine]. Derzhavne upravlinnia: udoskonalennia ta rozvytok, no. 3 (2020). DOI: 10.32702/2307-2156-2020.3.2

[Legal Act of Ukraine] (2010). https://zakon.rada.gov.ua/ laws/show/2404-17\#Text

[Legal Act of Ukraine] (2013). https://zakon.rada.gov.ua/ laws/show/739-2013-p

[Legal Act of Ukraine] (2019). https://zakon.rada.gov.ua/ laws/show/997-14

"Ministry of Infrastructure of Ukraine. (2021). Who we are". https://mtu.gov.ua/en/content/hto-mi-e.html

Mishenin, Ye. "Kontseptualni zasady rozvytku mekhanizmiv derzhavno-pryvatnoho partnerstva v lisoresursnii sferi" [Conceptual Bases of Development of Mechanisms of Public-private Partnership in the Forest Resource Sphere]. Ekonomist, no. 12 (2010): 23-26.

Mishenina, N. V., Yarova, I. Ye., and Mishenina, H. A. "Rozvytok mekhanizmiv derzhavno-pryvatnoho partnerstva u sferi pryrodohospodariuvannia v umovakh detsentralizatsii" [Development of Mechanisms of Public-private Partnership in the Field of Nature Management in the Conditions of Decentralization]. Marketynh i menedzhment innovatsii. 2017. http://nbuv.gov.ua/UJRN/ Mimi_2017_1_31

Onehina, V. M., and Batiuk, L. A. "Derzhavno-pryvatne partnerstvo ta rozvytok silskykh terytorii $v$ Ukraini" [Public-private Partnership and Rural Development in Ukraine]. Aktualni problemy innovatsiinoi ekonomiky. 2017. http://nbuv.gov.ua/UJRN/ apie_2017_2_11

"Shchodo rozvytku derzhavno-pryvatnoho partnerstva yak mekhanizmu aktyvizatsii investytsiinoi diialnosti v Ukraini : analit. zapyska" [On the Development of Public-private Partnership as a Mechanism for Intensifying Investment Activities in Ukraine: An Analytical Note]. Natsionalnyi instytut stratehichnykh doslidzhen. https://niss.gov.ua/doslidzhennya/ekonomika/schodo-rozvitkuderzhavno-privatnogo-partnerstva-yak-mekhanizmu-aktivizacii

Valaguzza, S., and Parisi, E. Public Private Partnerships: Governing Common Interests. 2020.

Van Ham, H. "Public-Private Partnerships: Assessing and Managing Risks in Port Development". Public Management Review, vol. 3 (4) (2011): 593-616.

Varnavskiy, V. G., Klimenko, A. V., and Korolev, V. A. Gosudarstvenno-chastnoye partnerstvo: teoriya i praktika [Public-private Partnership: Theory and Practice]. Moscow: GU-VShE, 2010.

Vynnytskyi, B. et al. “Dosvid ta perspektyvy vprovadzhennia derzhavno-pryvatnykh partnerstv v Ukraini ta za kordonom" [Experience and Prospects for the Implementation of Public-private Partnerships in Ukraine and Abroad]. Kyiv : K.I.S., 2008. https://regionet.org.ua/files/PPP_Report_CIDA_2008_ua.pdf

Стаття надійшла до редакції 26.10.2021р. 